\title{
Nelson's syndrome: a review of the clinical manifestations, pathophysiology, and treatment strategies
}

\author{
Jimmy Patel, BS, ${ }^{1}$ Jean Anderson Eloy, MD, ${ }^{1-3}$ and James K. Liu, MD ${ }^{1-3}$ \\ Departments of ${ }^{1}$ Neurological Surgery and ${ }^{2}$ Otolaryngology-Head and Neck Surgery, and ${ }^{3}$ Center for Skull Base and Pituitary
} Surgery, Neurological Institute of New Jersey, Rutgers University, New Jersey Medical School, Newark, New Jersey

\begin{abstract}
Nelson's syndrome is a rare clinical manifestation that occurs in $8 \%-47 \%$ of patients as a complication of bilateral adrenalectomy, a procedure that is used to control hypercortisolism in patients with Cushing's disease. First described in 1958 by Dr. Don Nelson, the disease has since become associated with a clinical triad of hyperpigmentation, excessive adrenocorticotropin secretion, and a corticotroph adenoma. Even so, for the past several years the diagnostic criteria and management of Nelson's syndrome have been inadequately studied. The primary treatment for Nelson's syndrome is transsphenoidal surgery. Other stand-alone therapies, which in many cases have been used as adjuvant treatments with surgery, include radiotherapy, radiosurgery, and pharmacotherapy. Prophylactic radiotherapy at the time of bilateral adrenalectomy can prevent Nelson's syndrome (protective effect). The most promising pharmacological agents are temozolomide, octreotide, and pasireotide, but these agents are often administered after transsphenoidal surgery. In murine models, rosiglitazone has shown some efficacy, but these results have not yet been found in human studies. In this article, the authors review the clinical manifestations, pathophysiology, diagnostic criteria, and efficacy of multimodal treatment strategies for Nelson's syndrome.
\end{abstract}

http://thejns.org/doi/abs/10.3171/2014.10.FOCUS14681

KEY WORDS Nelson's syndrome; Cushing's disease; ACTH; pituitary adenoma

$\mathrm{T}$ HE primary treatment for Cushing's disease is transsphenoidal adenomectomy; ${ }^{12,22,76}$ remission rates are $70 \%-90 \% .^{6,12,72,79}$ In a meta-analysis of 50 studies performed by Roelfsema et al., biochemical remission was found for 4207 (72.7\%) of 5787 patients who had undergone a single surgical procedure. ${ }^{72}$ However, refractory hypercortisolemia from persistent or recurrent Cushing's disease remains a therapeutic challenge. ${ }^{65}$ Treatment options for Cushing's disease after unsuccessful transsphenoidal surgery include repeat transsphenoidal surgery, radiation therapy, medical therapy, and bilateral adrenalectomy. ${ }^{13,38,47}$ Bilateral adrenalectomy represents a safe and effective definitive procedure for patients who need immediate treatment for hypercortisolemia or who have been unresponsive to multiple therapies for refractory Cushing's disease..$^{45,47}$

In 1958, Dr. Don Nelson et al. reported a case in which a 33-year-old woman, who had undergone bilateral adrenalectomy for Cushing's disease 3 years earlier, experi- enced skin hyperpigmentation, high plasma levels of adrenocorticotropic hormone (ACTH), and ultimately a pituitary tumor. ${ }^{59}$ By the 1960 s, Nelson and other colleagues found that after bilateral adrenalectomy, ACTH-producing pituitary tumors appeared in several patients, thus leading to increased levels of ACTH and hyperpigmentation. Hence, these 3 symptoms have since become the clinical triad of Nelson's syndrome. ${ }^{60,61}$ Since its initial description in $1958,{ }^{59}$ Nelson's syndrome has caused concern for physicians treating refractory Cushing's disease with bilateral adrenalectomy. Although Nelson's syndrome is rare, therapies have varied. With the advancements in neuroimaging and endocrinology, Nelson's syndrome can be detected very early in its course. Treatment options include observation, surgery, radiation therapy, and pharmacotherapy. We review the clinical manifestations, pathophysiology, and incidence of Nelson's syndrome; delineate diagnostic methods; and outline the various treatment modalities that have been used to alleviate symptoms.

ABBREVIATIONS ACTH = adrenocorticotropic hormone; FSRT = fractionated stereotactic radiotherapy; GK = Gamma Knife; SRS = stereotactic radiosurgery; sst = somatostatin receptor.

SUBMITTED October 2, 2014. ACCEPTED October 30, 2014.

INCLUDE WHEN CITING DOI: 10.3171/2014.10.FOCUS14681.

DISCLOSURE The authors report no conflict of interest concerning the materials or methods used in this study or the findings specified in this paper. 


\section{Diagnosis and Clinical Features}

After a patient undergoes bilateral adrenalectomy for Cushing's disease, the chance of Nelson's syndrome development ranges from $8 \%$ through $47 \%$. $^{2,4,8,19,31,34,38,47,51}$ The presentation of Nelson's syndrome is variable and depends on the extent of adrenalectomy, length between surgery and presentation, and the source of hypercortisolemia (potentially ectopic sources). ${ }^{31}$ When radiation therapy is used to treat an ACTH-secreting pituitary tumor after Nelson's syndrome has developed, it is considered as a therapeutic measure for Nelson's syndrome. However, when pituitary radiation therapy is undertaken before or immediately after bilateral adrenalectomy but before Nelson's syndrome has developed, it is considered a prophylactic measure that can potentially prevent the development of Nelson's syndrome. ${ }^{21,25,33,39}$ The signs and symptoms used to diagnose Nelson's syndrome are elevated plasma ACTH levels, hyperpigmentation, and tumor progression (Figs. 1-3). These tumors are capable of invading the cavernous sinus and compressing cranial nerves and optic pathways. In a recent case, bilateral oculomotor palsy was present in a patient with Nelson's syndrome. ${ }^{23}$

\section{Pathophysiology}

Cortisol is a steroid hormone produced in the zona fasciculata of the adrenal cortex. In normal physiological systems, it provides negative feedback on the release of corticotropin-releasing hormone produced by the hypothalamus. Bilateral adrenalectomy is meant to curb hypercortisolemia in patients with Cushing's disease, thus releasing the system from the negative-feedback loop. Along the same line, without negative feedback, it is hypothesized that corticotropin-releasing hormone levels increase, leading to increased production of proopiomelanocortin and its subsequent products ACTH and melanocyte-stimulating hormone. In a study of pituitary tissue from patients with Nelson's syndrome, the tumor was monoclonal

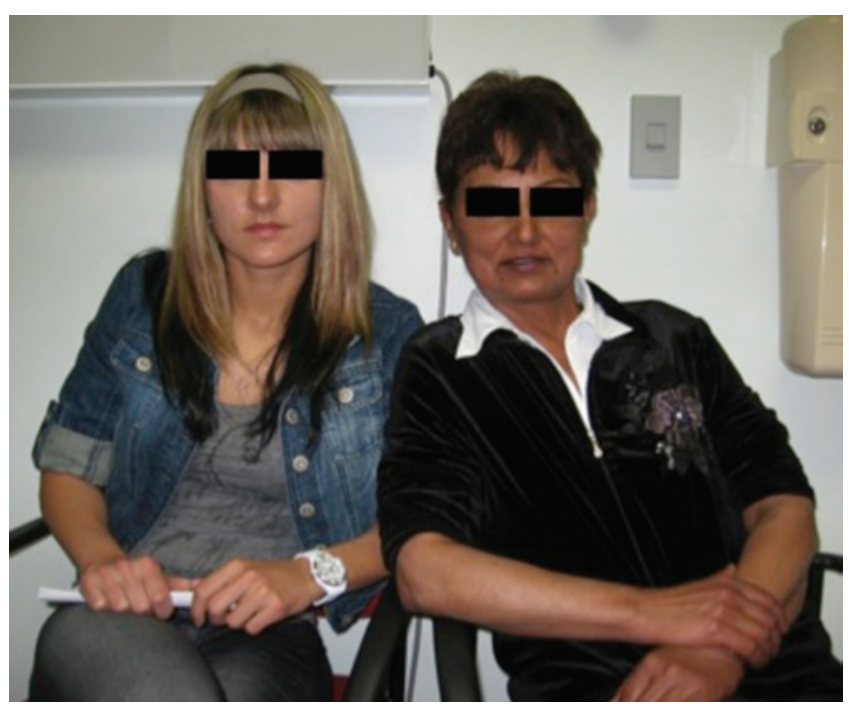

FIG. 1. Photograph of 51-year-old woman with Nelson's syndrome (on right), taken 15 years after undergoing bilateral adrenalectomy for Cushing's disease. Hyperpigmentation of her skin was very noticeable, as distinguished from the lighter skin of her daughter (on left).
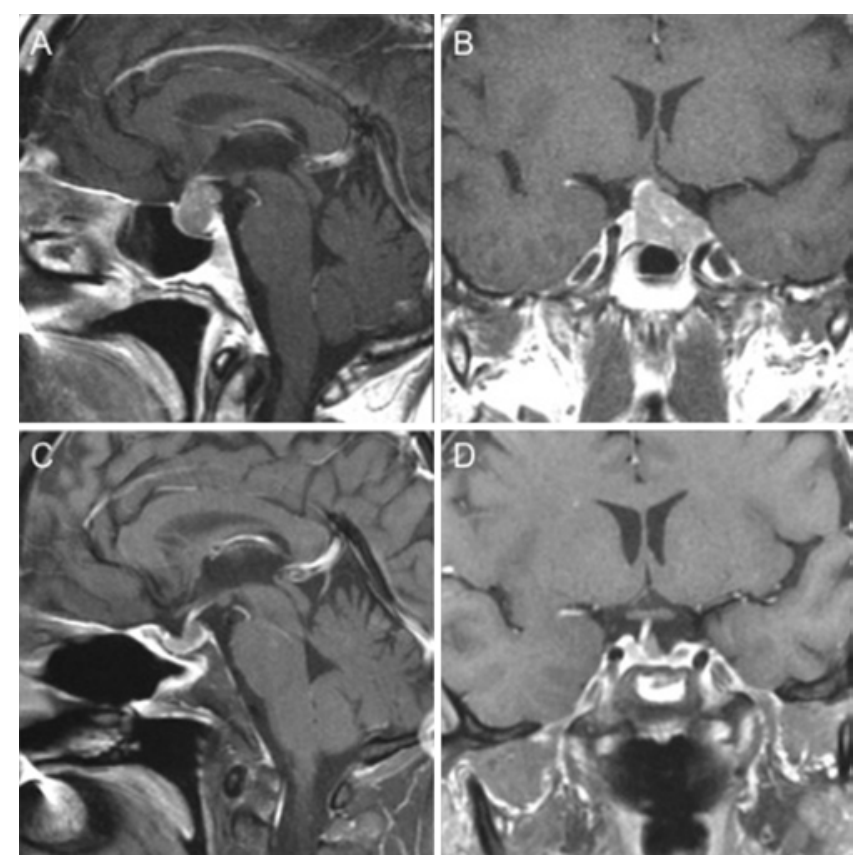

FIG. 2. Preoperative post-Gd MR images (sagittal [A] and coronal [B]) of the patient in Fig. 1, showing an ACTH-secreting pituitary macroadenoma with optic chiasm compression. Postoperative postgadolinium MR images (sagittal [C] and coronal [D]) after endoscopic endonasal transsphenoidal resection. A small remnant can be seen at the base of the pituitary stalk. Plasma ACTH dropped from over $2000 \mathrm{pg} / \mathrm{ml}$ to 418 $\mathrm{pg} / \mathrm{ml}$. The residual tumor was further treated with SRS.

and proopiomelanocortin mRNA and gene products were unaltered. ${ }^{2,14,20,29,69}$ In murine models, adrenalectomy led to increased corticotroph cell numbers, corticotroph cell hyperplasia, increased expression of arginine vasopressin, and increased levels of corticotropin-releasing hormone and proopiomelanocortin-derived gene products..$^{10,52,89} \mathrm{In}$ a previous work, ACTH-secreting pituitary tumors were shown to overexpress vasopressin V3 and corticotropinreleasing hormone receptor genes; this finding is crucial because it was previously shown that both arginine vasopressin and corticotropin-releasing hormone induce proliferation in a corticotropic tumor cell line. ${ }^{15,82}$ Also with regard to negative feedback, in the aforementioned in vitro model, proliferation of the tumor cell line was significantly inhibited by cortisol, and ACTH secretion by the tumor cell line was increased after incubation with corticotropinreleasing hormone but not with arginine vasopressin. ${ }^{82}$ In a separate in vitro study, cortisol suppressed RNA and DNA synthesis in ACTH-secreting human pituitary tumor cell lines, which also confirms the negative-feedback loop. ${ }^{71}$ Of note, somatostatin-14 and somatostatin-28 suppressed secretion of proopiomelanocortin-derived peptides from a pituitary adenoma causing Nelson's syndrome, but arginine vasopressin, vasoactive intestinal peptide, and oxytocin stimulated secretion of proopiomelanocortin-derived peptides. $^{74}$ In patients with Nelson's syndrome, continuous infusion of synthetic ovine corticotropin-releasing hormone at $1 \mu \mathrm{g}$ per kilogram per hour led to increased plasma ACTH, without desensitization of ACTH secretion. ${ }^{62}$ In contrast, ovine corticotropin-releasing hormone did not stimulate ACTH secretion at concentrations from 


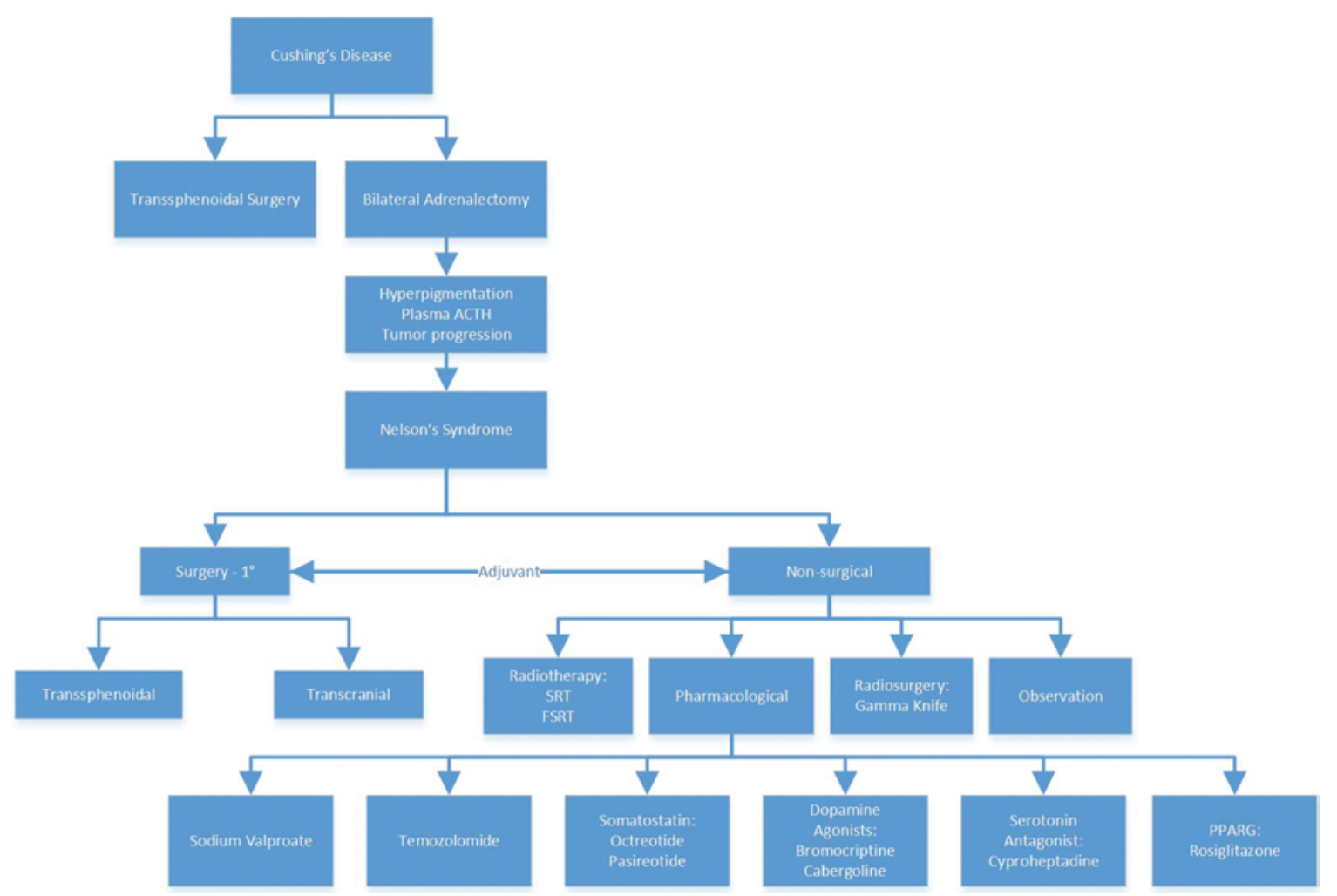

FIG. 3. Major treatment options for Cushing's disease and Nelson's syndrome (not all of the possible treatments for Cushing's disease are included). Prophylactic radiotherapy at the time of bilateral adrenalectomy may have a highly protective effect in preventing Nelson's syndrome. Transsphenoidal surgery remains the primary treatment for the management of Nelson's syndrome. Nonsurgical treatments can either be stand-alone or used as adjuvants to surgery. Temozolomide, octreotide, and pasireotide show the most promise as pharmacotherapies, but they are often administered after transsphenoidal surgery. The usefulness of sodium valproate is still inconclusive. The usefulness of cabergoline has been shown in some studies, but that of other dopamine agonists is inconclusive. Rosiglitazone has shown some efficacy in murine models, but these results have not yet been found in human studies. PPARG $=$ peroxisome proliferator-activated receptor $\gamma$.

$1 \times 10^{-13} \mathrm{M}$ through $1 \times 10^{-7} \mathrm{M}$ in pituitary adenomas resected from patients with Nelson's syndrome. ${ }^{75}$ Based on these studies, an additional hypothesis can be developed, suggesting that if a patient with Cushing's disease had a residual corticotroph adenoma and underwent bilateral adrenalectomy, then the resulting increased arginine vasopressin and corticotropin-releasing hormone would lead to the corticotroph tumor progression that has now become characteristic of Nelson's syndrome.

\section{Predictive Factors}

Multiple factors have been linked to onset of Nelson's syndrome. As mentioned, presence of a residual pituitary adenoma before bilateral adrenalectomy has been associated with the development of Nelson's syndrome. .1,33,66,77 $^{21,}$ Presence of an adenoma at the time of surgery or on neuroimages has been shown to predict the onset of Nelson's syndrome, particularly in patients with larger tumors (macroadenomas with cavernous sinus involvement). In one series, among 20 patients who had undergone adrenalectomy after hypophysectomy, residual tumor was documented in 9; of these 9 patients, Nelson's syndrome developed in $2(22 \%){ }^{21}$ These 2 patients did not receive prophylactic radiotherapy, which brings this discussion to the next predictive factor. It has been suggested that prophylactic pituitary radiotherapy at the time of bilateral adrenalectomy might serve a protective role in reducing the risk for development of Nelson's syndrome or possibly delaying its onset. ${ }^{21,25,33,39}$ In a study by Gil-Cárdenas et al., Nelson's syndrome developed in 11 patients, none of whom had received prophylactic radiation therapy. ${ }^{21}$ One of the best predictive factors for Nelson's syndrome is high levels of ACTH after adrenalectomy, but no definitive threshold value has been established. . $18,33,34,51,55,66$ A rapid rise of plasma ACTH levels in the first year after bilateral adrenalectomy seems to be a strong predictor because of its association with tumor progression. ${ }^{5,51}$ Some studies have suggested young age at the time of bilateral adrenalectomy as a predictive factor, but this finding has not been consistent. ${ }^{32,42,54,58,77,78}$ Also, the duration of Cushing's disease before bilateral adrenalectomy might have some role in the development of Nelson's syndrome; however, in many case series, this association has not been shown. ${ }^{41,42,58,77}$ Patient sex could be a predictive factor, ${ }^{16,21,42,58,66,77}$ and in several studies, high urinary cortisol has been associated with Nelson's syndrome. ${ }^{25,58,77}$

\section{Treatment Strategies \\ Observation}

Although some clinicians may consider initial observation with repeat imaging for Nelson's syndrome patients 
harboring smaller, stable tumors that have not grown or that have demonstrated limited progression, observation is generally not the first line of treatment. If left untreated, most of these tumors will probably progress and warrant treatment. In a study by Kemink et al., observation was the treatment modality for 8 of 15 patients. ${ }^{43}$ In these 8 patients, ACTH levels increased between the time of diagnosis and the time of the last follow-up visit, and in all 8 patients, the tumor progressed with parasellar extension or suprasellar extension. Of these 8 patients, 6 underwent elective pituitary surgery.

\section{Surgical Treatment}

The first line of treatment for Nelson's syndrome is resection, which is performed primarily via a transsphenoidal approach or, less commonly, via a transcranial approach. One of the first reports of pituitary surgery for Nelson's syndrome was by Espinoza et al., who described 3 patients who had undergone transsphenoidal surgery for the removal of the ACTH-secreting pituitary adenomas (Table 1). ${ }^{18}$ Surgical treatment enables potentially curative resection of the expanding corticotroph tumor and decompression of the optic chiasm, if needed. Unfortunately, considering the rarity of Nelson's syndrome, not many long-term case series for this surgery have been studied, and with the current advancements in nonsurgical therapies, the likelihood of finding any such series will decrease. Kelly et al. attempted total hypophysectomy on 13 patients with Nelson's syndrome ${ }^{39} ; 9$ patients underwent transsphenoidal resection and 4 underwent transcranial resection ( 2 by subfrontal approach and 2 by pterional approach). Tumor recurred in 2 patients, both of whom had undergone transsphenoidal resection; however, no regrowth occurred in patients who had undergone transcranial resection. De Tommasi et al. reported on 6 patients with Nelson's syndrome who had undergone transsphenoidal surgery. ${ }^{16}$ Two patients had extrasellar extension. In all 6 patients, the adenoma persisted after the first transsphenoidal surgery; half of these patients subsequently underwent repeat transsphenoidal surgery and half underwent Gamma Knife (GK) radiosurgery. Remission occurred in only 1 patient; disease persisted for the remainder. The range of efficacy of resection for treatment of Nelson's syndrome is $10 \%-70 \%$. Complications can include CSF leaks, cranial nerve deficits, meningitis, and visual field defects. ${ }^{3,24,39,49}$

\section{Radiotherapy and Radiosurgery}

Radiotherapy can be considered as an option for patients in whom surgery for Nelson's syndrome was unsuccessful or patients who are not optimal surgical candidates. One pitfall of radiotherapy is that it does not immediately reduce and normalize ACTH levels. Achieving normal ACTH levels can take weeks to months, depending on the size of the tumor; in the interim, control of excessive ACTH must be achieved by another manner such as medical therapy. Potential complications of radiation therapy include radiation-induced optic neuropathy, hypopituitarism, radiation necrosis, cerebral edema, and vasculopathy ${ }^{83}$ Radiation therapy can also be used as an adjunctive treat- ment. ${ }^{39}$ More conformal techniques such as fractionated stereotactic radiotherapy (FSRT) or proton beam therapy can help reduce the adverse effects of disseminated radiation. For prevention of optic nerve injury, brain necrosis, and damage to surrounding tissues, the typical radiation dose (approximately 45-50 Gy) is given at 1.8- to 2.0-Gy fractions. ${ }^{3,46,64}$ Some investigators suggest that neoadjuvant radiation therapy after bilateral adrenalectomy may protect and possibly delay development of Nelson's syndrome. ${ }^{33,39}$ According to a review of 39 patients followed up over 15 years after bilateral adrenalectomy, Nelson's syndrome did not develop in any patients who had received neoadjuvant radiation therapy but did develop in $50 \%$ of those who did not. ${ }^{21}$ Although there is currently no consensus as to the role of neoadjuvant prophylactic radiation therapy, it has been the practice at the University of Oxford to administer it to patients with residual pituitary tissue who will undergo bilateral adrenalectomy. ${ }^{4}$ However, further definitive follow-up data are pending.

Stereotactic radiosurgery (SRS) directs several beams of low-powered radiation to a specific target in the brain by a 3D coordination system. Although the low-powered beams prevent collateral radiation injury to the brain, a strong radiation dose is delivered to the point of convergence. One of the more common radiosurgical techniques used to manage Cushing's disease is GK radiosurgery.,43,50,85,70 Vik-Mo et al. published a study in which 10 patients with Nelson's syndrome underwent GK treatment. ${ }^{84}$ On average, tumor volume decreased by $32 \%$ for 9 patients but not at all for 1 patient. Of these 10 patients, ACTH levels decreased for 8 (range 2.0-278 pmol/L) and reached normal range for only 1 patient. However, the authors do not define their normal range for ACTH nor reveal the plasma ACTH levels for this patient. Recently, Marek et al. reported a study of 14 patients with Nelson's syndrome treated by GK radiosurgery in which the average follow-up period was 10.4 years. ${ }^{50}$ Of these 14 patients, plasma ACTH levels decreased gradually in 12 and achieved normal levels 13-14 years later in 2. At approximately 2-5 years postirradiation, adenoma volume had decreased in 7 patients, remained unchanged in 6 patients, and completely disappeared in 1 patient. At 5-10 years after irradiation, among 11 patients reassessed, tumor volume decreased in 5 patients, remained unchanged in 3 patients, completely disappeared in 2 patients, and regrew in 1 patient. Most recently, Wilson et al. published a report about use of a linear accelerator for SRS (5 patients) and FSRT (2 patients). ${ }^{87}$ After SRS, tumor volume decreased for 2 patients, increased in another 2 patients, and did not change in 1 patient. After FSRT, tumor volume decreased for 1 patient and increased after 15 months for the other. Unfortunately, no data concerning posttreatment ACTH levels were available. For patients in whom residual tumor is adjacent or in close approximation to the optic apparatus $(<2-3 \mathrm{~mm})$, it might be safer to use FSRT rather than SRS to avoid radiation-induced optic nerve injury.

\section{Medical Therapy}

Medicinal therapy aims to control ACTH levels and curb tumor growth; however, no consistent series have confirmed its efficacy. Pharmacotherapies include sodium 
TABLE 1. Treatment modalities for Nelson's syndrome stratified by year of publication

\begin{tabular}{|c|c|c|c|c|c|c|}
\hline Authors \& Year & $\begin{array}{l}\text { No. of } \\
\text { Pts }\end{array}$ & $\begin{array}{c}\text { Mean } \\
\text { Age (yrs) }\end{array}$ & Treatment Modality & Outcome & Mean FU & Dosage \\
\hline $\begin{array}{l}\text { Espinoza et al., } \\
\quad 1973\end{array}$ & 3 & NA & Transsphenoidal microsurgery & $\begin{array}{l}\text { ACTH at reference levels }(5 \mathrm{mU} / 100 \\
\mathrm{ml} \text { plasma) for } 2 \mathrm{pts} \text {, levels re- } \\
\text { duced (from } 25 \text { to } 7 \mathrm{mU} / 100 \mathrm{ml} \\
\text { plasma) for } 1 \mathrm{pt}\end{array}$ & NA & \\
\hline Tyrell et al., 1975 & 5 & 31.8 & Somatostatin & $\begin{array}{l}\text { ACTH levels decreased avg } 52 \% \\
\text { from baseline }\end{array}$ & NA & $500 \mu \mathrm{g} / 1 \mathrm{hr}$ \\
\hline $\begin{array}{l}\text { Dornhorst et al., } \\
1983\end{array}$ & 10 & & Sodium valproate & $\begin{array}{l}\text { ACTH drop from } 2460 \text { to } 480 \mathrm{ng} / \mathrm{L} \\
\text { in } 3 \text { wks, back to pretreatment } \\
\text { values by } 5-12 \text { wks; reduced } \\
\text { tumor size }(1 / 10 \mathrm{pts})\end{array}$ & NA & $\begin{array}{l}600-1200 \mathrm{mg}, 5-12 \\
\text { wks }\end{array}$ \\
\hline Kelly et al., 1988 & 11 & 45 & Sodium valproate & No significant ACTH changes in $1 \mathrm{yr}$ & NA & $600-1200$ mg/day \\
\hline $\begin{array}{l}\text { Kelestimur et al., } \\
\quad 1996\end{array}$ & 1 & 27 & Octreotide & $\begin{array}{l}\text { Approx } 54 \% \text { decrease in plasma } \\
\text { ACTH }\end{array}$ & NA & $100 \mu \mathrm{g} / 3 \times$ day $/ 7$ days \\
\hline \multirow{6}{*}{$\begin{array}{l}\text { Mercado-Asis et } \\
\text { al., } 1997\end{array}$} & 6 & 41 & Bromocriptine & $52 \%$ decrease in plasma ACTH & NA & $2.5 \mathrm{mg}$ \\
\hline & & & Cyproheptadine & $17 \%$ decrease in plasma ACTH & NA & $8 \mathrm{mg}$ \\
\hline & & & Valproic acid & $37 \%$ decrease in plasma ACTH & NA & $1 \mathrm{~g}$ \\
\hline & & & Cyproheptadine + valproic acid & $19 \%$ decrease in plasma ACTH & NA & $8 m g+1 g$ \\
\hline & & & All 3 combined & $58 \%$ decrease in plasma ACTH & NA & $2.5 m g+8 m g+1 g$ \\
\hline & & & Placebo & $6 \%$ decrease in plasma ACTH & NA & \\
\hline $\begin{array}{l}\text { Wolffenbuttel et } \\
\quad \text { al., } 1988\end{array}$ & 1 & 50 & GK & Minor reduction in tumor size & $>2.0 \mathrm{yrs}$ & $40 \mathrm{~Gy}$ \\
\hline \multirow{3}{*}{$\begin{array}{l}\text { Kemink et al., } \\
2001\end{array}$} & 15 & 40.3 & Observation only (2 pts) & Remission (0/2 pts) & $4.0 \mathrm{yrs}$ & \\
\hline & & & Elective pituitary surgery (11 pts) & Remission (4/11 pts) & $10.1 \mathrm{yrs}$ & \\
\hline & & & RT only (2 pts) & Remission (0/2 pts) & $9.5 \mathrm{yrs}$ & 40-50 Gy \\
\hline \multirow[t]{2}{*}{ Kelly et al., 2002} & 13 & $\begin{array}{c}35 \text { at } 1 \text { st } \\
\text { op }\end{array}$ & Transsphenoidal surgery (9 pts) & Regrowth (2/9 pts) & $15.2 \mathrm{yrs}$ & \\
\hline & & & Transcranial surgery (4 pts) & Regrowth (0/4 pts) & $16.8 \mathrm{yrs}$ & \\
\hline $\begin{array}{l}\text { Pollock \& Young, } \\
2002\end{array}$ & 11 & 42 & GK (11 pts) & $\begin{array}{l}\text { Stable tumor size (6/11 pts), de- } \\
\text { creased tumor size }(3 / 11 \mathrm{pts}) \\
\text { increased tumor size (2/11 pts) }\end{array}$ & $3.08 \mathrm{yrs}$ & Avg 40 Gy \\
\hline \multirow[t]{3}{*}{$\begin{array}{l}\text { Casulari et al., } \\
2004\end{array}$} & 1 & 26 & Cyproheptadine & $\begin{array}{l}\text { ACTH drop from } 2850 \text { to } 112 \mathrm{pg} / \mathrm{ml} \\
\text { but no change in tumor size }\end{array}$ & $>4.0$ yrs & $12 \mathrm{mg} /$ day for $18 \mathrm{mos}$ \\
\hline & & & Cabergoline & $\begin{array}{l}\text { ACTH drop to } 38 \mathrm{pg} / \mathrm{ml} \& \text { tumor } \\
\text { regression }\end{array}$ & & $0.5 \mathrm{mg} / 2 \times \mathrm{wk} / 1 \mathrm{yr}$ \\
\hline & & & Bromocriptine & ACTH increase from 38 to $247 \mathrm{pg} / \mathrm{ml}$ & & $7.5 \mathrm{mg} / \mathrm{day} / 6 \mathrm{mos}$ \\
\hline \multirow[t]{2}{*}{$\begin{array}{l}\text { De Tomassi et } \\
\text { al., } 2005\end{array}$} & 6 & 55.5 & $\begin{array}{l}\text { Transsphenoidal surgery (repeated } \\
\text { 2-3 times) }\end{array}$ & Remission (1/3 pts) & NA & \\
\hline & & & $\begin{array}{l}\text { Transsphenoidal surgery (repeated } \\
3 \text { times) + GK }\end{array}$ & Remission (0/3 pts) & NA & \\
\hline $\begin{array}{l}\text { Mullan et al., } \\
2006\end{array}$ & 7 & 55.8 & Rosiglitazone & No significant ACTH drop in 12 wks & 12 wks & $7 \mathrm{mg} / \mathrm{day} / 12 \mathrm{wks}$ \\
\hline $\begin{array}{l}\text { Gil-Cárdenas et } \\
\quad \text { al., } 2007\end{array}$ & 11 & 28 & $\begin{array}{l}\text { RT only ( } 3 \text { pts), RT + valproic acid } \\
\text { ( } 3 \text { pts), hypophysectomy ( } 3 \text { pts), } \\
\text { valproic acid (1 pt), RT + valproic } \\
\text { acid + hypophysectomy ( } 1 \text { pt) }\end{array}$ & $\begin{array}{l}\text { Tumor stable in } 6 / 8 \text { pts not treated } \\
\text { surgically }\end{array}$ & NA & \\
\hline $\begin{array}{l}\text { Vik-Mo et al., } \\
2009\end{array}$ & 10 & 47 & GK (10 pts) & $\begin{array}{l}32 \% \text { decrease in avg tumor vol }(9 / 10 \\
\text { pts) }\end{array}$ & $7.0 \mathrm{yrs}$ & Avg 53.4 Gy \\
\hline $\begin{array}{l}\text { Moyes et al., } \\
2009\end{array}$ & 1 & 64 & Temozolomide & $\begin{array}{l}\text { ACTH drop } 2472 \text { to } 389 \mathrm{pmol} / \mathrm{L} \text {; de- } \\
\text { creased tumor size }\end{array}$ & NA & $\begin{array}{r}200 \mathrm{mg} / \mathrm{m}^{2} \text { orally for } 5 \\
\text { days, } 28 \text {-day cycle }\end{array}$ \\
\hline
\end{tabular}


TABLE 1. Treatment modalities for Nelson's syndrome stratified by year of publication (continued)

\begin{tabular}{|c|c|c|c|c|c|c|}
\hline Authors \& Year & $\begin{array}{l}\text { No. of } \\
\text { Pts }\end{array}$ & $\begin{array}{c}\text { Mean } \\
\text { Age (yrs) }\end{array}$ & Treatment Modality & Outcome & Mean FU & Dosage \\
\hline $\begin{array}{l}\text { Katznelson, } \\
2013\end{array}$ & 1 & 55 & Pasireotide & $\begin{array}{l}\text { Decreased plasma ACTH from } \\
42,710 \mathrm{pg} / \mathrm{ml} \text { to } 4272 \mathrm{pg} / \mathrm{ml} \text {; tumor } \\
\text { reduction }\end{array}$ & $19 \mathrm{mos}$ & $\begin{array}{l}60 \text { mg intramuscularly, } \\
\text { 28-day cycle }\end{array}$ \\
\hline \multirow{3}{*}{$\begin{array}{l}\text { Wilson et al., } \\
2014\end{array}$} & 19 & 49 & SRS (5 pts) & Reduced tumor vol (2/5 pts) & $4.40 \mathrm{yrs}$ & 20.0 Gy total \\
\hline & & & FSRT (2 pts) & Reduced tumor vol (1/2 pts) & $6.72 \mathrm{yrs}$ & 49.3 Gy total \\
\hline & & & Conventional RT (12 pts) & & $3.15 \mathrm{yrs}$ & 50.0 Gy total \\
\hline $\begin{array}{l}\text { Marek et al., } \\
2014\end{array}$ & 14 & 39.8 & $14 \mathrm{GK}$ & $\begin{array}{l}\text { Decrease plasma ACTH (12 pts), } \\
\text { normalization (2 pts); tumor de- } \\
\text { crease (10 pts), stable (3 pts), } \\
\text { regrowth (1 pt) }\end{array}$ & $10.4 \mathrm{yrs}$ & Avg 56.0 Gy \\
\hline $\begin{array}{l}\text { Arregger et al., } \\
2014\end{array}$ & 1 & 59 & Octreotide & $\begin{array}{l}\text { ACTH drop from } 235 \mathrm{pM} \text { to } 71 \mathrm{pM} \\
\text { by } 21 \text { mos }\end{array}$ & $1.8 \mathrm{yrs}$ & $20 \mathrm{mg} / \mathrm{mo}$ \\
\hline
\end{tabular}

Approx = approximately; avg = average; FU = follow-up; NA = not applicable; pt = patient; $\mathrm{RT}$ = radiation therapy.

valproate, temozolomide, selective somatostatin analogs, dopamine agonists, and peroxisome proliferator-activated receptor $\gamma$ agonists (Fig. 4).

Sodium valproate works as a therapeutic agent for Nelson's syndrome by inhibiting reuptake of $\gamma$-aminobutyric acid, which would decrease corticotropin-releasing hormone release by the hypothalamus. In a study by Dornhorst et al., 10 patients with Nelson's syndrome received 600-1200 mg of sodium valproate per day for 5-32 weeks. Although initial treatment successfully decreased plasma ACTH levels, when treatment was discontinued, ACTH returned to pretreatment levels within 5-12 weeks. ${ }^{17}$ In another study, 11 patients with Nelson's syndrome were given $600 \mathrm{mg}$ of sodium valproate per day. At 6 weeks, plasma ACTH levels had decreased slightly $(\mathrm{p}<0.05)$. Of these 11 patients, sodium valproate was continued for 6 patients $(600 \mathrm{mg} /$ day for 5 patients and $1200 \mathrm{mg} /$ day for 1 patient). At 1 year, ACTH levels had not changed significantly from pretreatment or 6 -week levels for the 6 patients taking sodium valproate or the 5 patients not taking sodium valproate. ${ }^{40}$ Even when other reports are taken into consideration, effectiveness of sodium valproate for Nelson's syndrome remains inconclusive..$^{35,48,70}$

Temozolomide is an orally administered alkylating agent capable of crossing the blood-brain barrier. Its active form is methyl-triazeno-imidazole-carboxamide, which methylates DNA at the $\mathrm{O}^{6}$ position of guanine. Methylation leads to mispairing with thymine, and continual mispairing eventually leads to apoptosis of the affected cell. The standard dosage of temozolomide is $150-200 \mathrm{mg} / \mathrm{m}^{2}$ for 5 days in a 28-day cycle. Temozolomide was first used as a treatment for a prolactin-secreting pituitary adenomas. ${ }^{44}$ Temozolomide has been used in over 30 cases of pituitary adenomas; for patients whose tumors respond to this treatment, hormone levels decrease almost immediately. ${ }^{63}$ Recently, Moyes et al. described a case in which a 64-year-old woman with Nelson's syndrome was given $200 \mathrm{mg} / \mathrm{m}^{2}$ of temozolomide orally for 5 days in a 28-day cycle. ${ }^{56}$ By the end of the fourth cycle, MR images showed markedly decreased tumor volume and plasma ACTH lev- els had fallen from 2472 to $389 \mathrm{pmol} / \mathrm{L}$. However, the patient experienced complications of CSF leakage from the ears and nostrils from tumor shrinkage, which abated after a bout of bacterial meningitis. Although temozolomide seems to be an effective and well-tolerated treatment for Nelson's syndrome, further studies with larger series and longer-term follow-up are warranted.

Somatostatin analogs such as octreotide have been used in the treatment of Nelson's syndrome. ${ }^{67} \mathrm{ACTH}$-secreting pituitary adenomas primarily express somatostatin receptor (sst) 5, sst1, and sst2. ${ }^{30,81}$ Octreotide has a strong binding affinity to sst 2 and only a moderate binding affinity to sst5.,73 One of the earliest reports was made in 1975, when Tyrrell et al. described a progressive decline in plasma ACTH levels (40\%-71\% of pretreatment basal values) in 5 patients who had been given somatostatin. ${ }^{80}$ After infusion cessation, ACTH values rose back to baseline levels. In a separate study, octreotide was given to a 27 -year-old Nelson's syndrome patient. Plasma ACTH levels fell 54\% from pretreatment values (from $66.7 \mathrm{pmol} / \mathrm{L}$ to $36 \mathrm{pmol} / \mathrm{L}$ ), and tumor diameter decreased by $3 \mathrm{~mm} .{ }^{37} \mathrm{In}$ a very recent quality of life assessment, the effect of long-acting repeatable octreotide was assessed in a 59-year-old woman with Nelson's syndrome. ${ }^{1}$ Pretreatment plasma ACTH levels of $235 \mathrm{pM}$ decreased to 116 and $71 \mathrm{pM}$ at 18 and 21 months, respectively, after the patient received long-acting repeatable octreotide. Hyperpigmentation also decreased. Even after 3 months without receiving octreotide, the patient remained stable but ACTH levels began to increase (266 $\mathrm{pM}$ ), thus corroborating the effects of octreotide.

In contrast to octreotide, pasireotide is a multireceptor ligand with high binding affinity to sst1, sst 2 , sst 3 , and sst5. In 2012, the US Food and Drug Administration approved the use of pasireotide for the treatment of Cushing's disease. ${ }^{973}$ In 2013, Katznelson ${ }^{36}$ reported favorable biochemical and clinical responses in a patient with Nelson's syndrome treated with pasireotide. The patient was a 55-year-old woman with an aggressive and persistent pituitary corticotroph adenoma previously treated with multiple transsphenoidal surgeries and fractionated radio- 

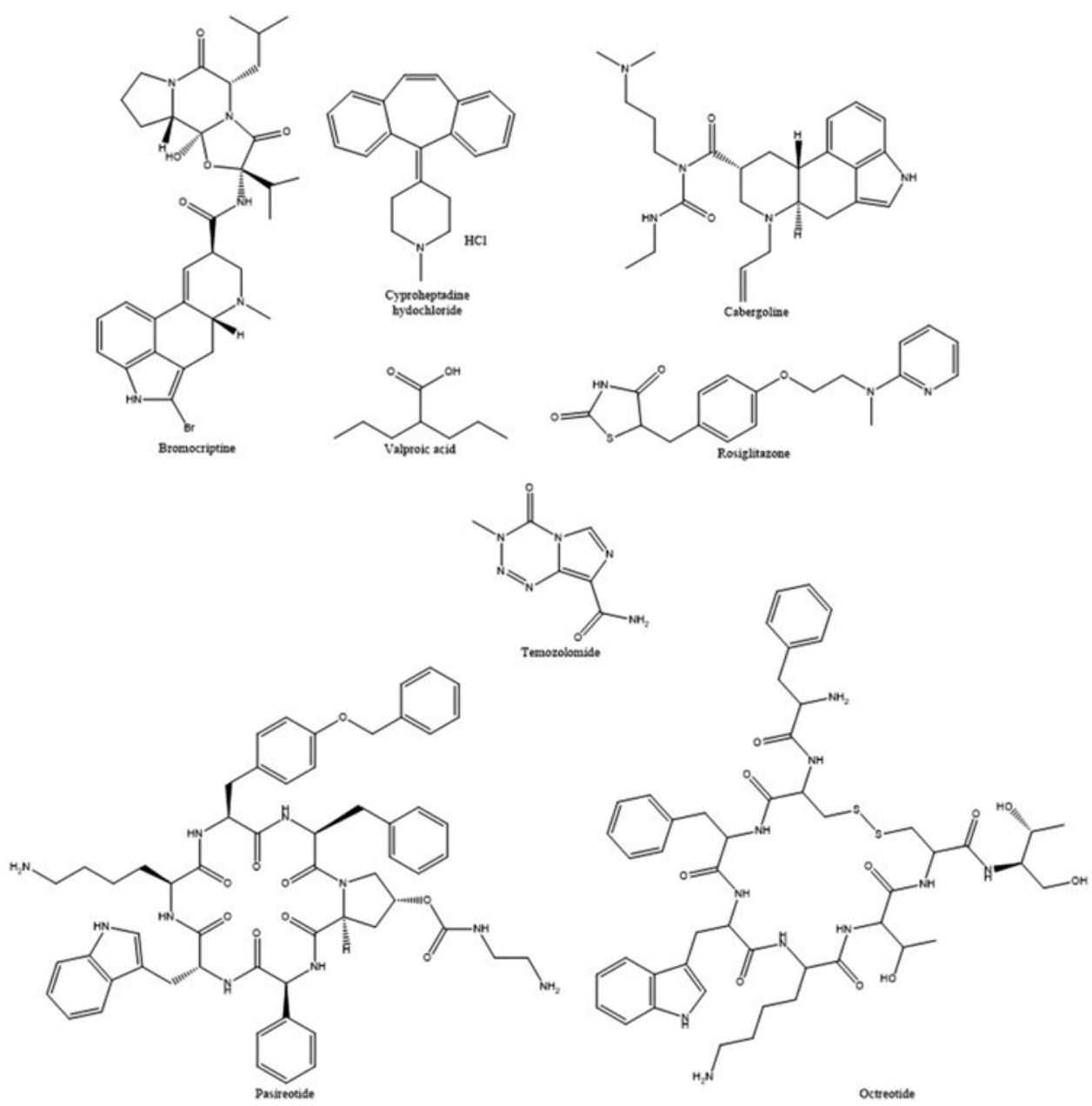

FIG. 4. Illustration depicting some of the pharmacological therapies that have been used in the treatment of Nelson's disease.

therapy. The patient received an intramuscular injection of $60 \mathrm{mg}$ of pasireotide every 28 days. The pretreatment baseline plasma ACTH level of $42,710 \mathrm{pg} / \mathrm{ml}$ (reference range 5-27 pg/ml) declined significantly, almost a thousand-fold, to $4272 \mathrm{pg} / \mathrm{ml}$, a month after treatment and remained around this level for approximately 19 months. In addition, the patient's skin hyperpigmentation decreased markedly. Follow-up MR imaging at 9 months showed a reduced size of the suprasellar component of the adenoma. Perhaps the greater binding affinity of pasireotide to sst5 makes it more effective than octreotide for treatment of Nelson's syndrome. Additional studies are warranted to corroborate the existing data for pasireotide as a treatment for Nelson's syndrome, and studies comparing octreotide with pasireotide should be considered.

Dopamine agonists such as bromocriptine and cabergoline have also been used in the medical management of patients with Nelson's syndrome. One study assessed the effects of bromocriptine, cyproheptadine (serotonin antagonist), and valproic acid on ACTH levels in 6 female patients with Nelson's syndrome.$^{53}$ Only bromocriptine at 2.5 $\mathrm{mg}$ caused a significant $(52 \%)$ decrease in plasma ACTH levels. In a different study, bromocriptine was ineffective at reducing plasma ACTH levels in a 26-year-old female Nelson's syndrome patient, but cabergoline successfully reduced levels from $247 \mathrm{pg} / \mathrm{ml}$ to $64 \mathrm{pg} / \mathrm{ml} .{ }^{11}$ According to MRI analysis, cabergoline also led to complete remission of the pituitary adenoma. The single and combined effects of cyproheptadine and bromocriptine were also tested in 12 patients who had raised plasma ACTH levels but no pituitary macroadenoma after bilateral adrenalectomy for Cushing's disease; plasma ACTH levels did not change significantly after treatment with this combination. ${ }^{86}$

Rosiglitazone, a thiazolidinedione, is a selective ligand of peroxisome proliferator-activated receptor $\gamma$. These receptors are abundantly expressed in human ACTHsecreting pituitary adenomas. Heaney et al. showed that rosiglitazone effectively prevented corticotroph tumors and suppressed ACTH secretion in murine models (150 $\mathrm{mg} / \mathrm{kg} / \mathrm{day}){ }^{26-28} \mathrm{In}$ in vitro studies, rosiglitazone induced $\mathrm{G}_{0} / \mathrm{G}_{1}$ cell-cycle arrest and apoptosis in human and murine corticotroph, somatolactotroph, and gonadotroph pituitary tumor cells and further suppressed hormone secretion. ${ }^{26}$ However, the favorable effects of rosiglitazone have not been successfully replicated in human studies. Mullan et al. presented a series of 7 patients with Nelson's syndrome for whom $8 \mathrm{mg}$ of rosiglitazone orally, once daily for 12 weeks, led to no statistically significant decrease in plasma ACTH levels. ${ }^{57}$ Of note, the US Food and Drug Administration limits the maximal dose of rosiglitazone in humans 
to $8 \mathrm{mg}$, but the murine models tested by Heaney and colleagues received $150 \mathrm{mg}$.

\section{Conclusions}

Nelson's syndrome remains a challenging neuroendocrine condition associated with significant morbidity after bilateral adrenalectomy for Cushing's disease. As treatments for Cushing's disease become more refined and shift away from bilateral adrenalectomy, the incidence of Nelson's syndrome will naturally decrease. This review should facilitate the diagnosis and understanding of the criteria of Nelson's syndrome. This description of therapies should be used to determine the best treatment strategy for a patient with Nelson's syndrome and should influence future investigations that may clarify current controversies with multimodal management.

\section{References}

1. Arregger AL, Cardoso EM, Sandoval OB, Monardes Tumilasci EG, Sanchez R, Contreras LN: Hormonal secretion and quality of life in Nelson syndrome and Cushing disease after long acting repeatable octreotide: a short series and update. Am J Ther 21:e110-e116, 2014

2. Assié G, Bahurel H, Bertherat J, Kujas M, Legmann P, Bertagna X: The Nelson's syndrome... revisited. Pituitary 7: 209-215, 2004

3. Banasiak MJ, Malek AR: Nelson syndrome: comprehensive review of pathophysiology, diagnosis, and management. Neurosurg Focus 23(3):E13, 2007

4. Barber TM, Adams E, Ansorge O, Byrne JV, Karavitaki N, Wass JA: Nelson's syndrome. Eur J Endocrinol 163:495507, 2010

5. Barnett AH, Livesey JH, Friday K, Donald RA, Espiner EA: Comparison of preoperative and postoperative ACTH concentrations after bilateral adrenalectomy in Cushing's disease. Clin Endocrinol (Oxf) 18:301-305, 1983

6. Boggan JE, Tyrrell JB, Wilson CB: Transsphenoidal microsurgical management of Cushing's disease. Report of 100 cases. J Neurosurg 59:195-200, 1983

7. Brada M, Ajithkumar TV, Minniti G: Radiosurgery for pituitary adenomas. Clin Endocrinol (Oxf) 61:531-543, 2004

8. Brunicardi FC, Rosman PM, Lesser KL, Andersen DK: Current status of adrenalectomy for Cushing's disease. Surgery 98:1127-1134, 1985

9. Bruns C, Lewis I, Briner U, Meno-Tetang G, Weckbecker G: SOM230: a novel somatostatin peptidomimetic with broad somatotropin release inhibiting factor (SRIF) receptor binding and a unique antisecretory profile. Eur J Endocrinol 146:707-716, 2002

10. Carey RM, Varma SK, Drake CR Jr, Thorner MO, Kovacs $\mathrm{K}$, Rivier J, et al: Ectopic secretion of corticotropin-releasing factor as a cause of Cushing's syndrome. A clinical, morphologic, and biochemical study. N Engl J Med 311:13-20, 1984

11. Casulari LA, Naves LA, Mello PA, Pereira Neto A, Papadia C: Nelson's syndrome: complete remission with cabergoline but not with bromocriptine or cyproheptadine treatment. Horm Res 62:300-305, 2004

12. Chen JC, Amar AP, Choi S, Singer P, Couldwell WT, Weiss MH: Transsphenoidal microsurgical treatment of Cushing disease: postoperative assessment of surgical efficacy by application of an overnight low-dose dexamethasone suppression test. J Neurosurg 98:967-973, 2003

13. Cuevas-Ramos D, Fleseriu M: Treatment of Cushing's disease: a mechanistic update. J Endocrinol 223:R19-R39, 2014

14. de Keyzer Y, Bertagna X, Lenne F, Girard F, Luton JP, Kahn
A: Altered proopiomelanocortin gene expression in adrenocorticotropin-producing nonpituitary tumors. Comparative studies with corticotropic adenomas and normal pituitaries. J Clin Invest 76:1892-1898, 1985

15. de Keyzer Y, René P, Beldjord C, Lenne F, Bertagna X: Overexpression of vasopressin (V3) and corticotrophin-releasing hormone receptor genes in corticotroph tumours. Clin Endocrinol (Oxf) 49:475-482, 1998

16. De Tommasi C, Vance ML, Okonkwo DO, Diallo A, Laws ER Jr: Surgical management of adrenocorticotropic hormone-secreting macroadenomas: outcome and challenges in patients with Cushing's disease or Nelson's syndrome. J Neurosurg 103:825-830, 2005

17. Dornhorst A, Jenkins JS, Lamberts SW, Abraham RR, Wynn $\mathrm{V}$, Beckford U, et al: The evaluation of sodium valproate in the treatment of Nelson's syndrome. J Clin Endocrinol Metab 56:985-991, 1983

18. Espinoza A, Nowakowski H, Kautzky R, Lüdecke D: ACTH determinations before and after selective removal of pituitary adenomas in Nelson's syndrome. Acta Endocrinol Suppl (Copenh) 173:34, 1973

19. Favia G, Boscaro M, Lumachi F, D’Amico DF: Role of bilateral adrenalectomy in Cushing's disease. World J Surg 18:462-466, 1994

20. Gicquel C, Le Bouc Y, Luton JP, Girard F, Bertagna X: Monoclonality of corticotroph macroadenomas in Cushing's disease. J Clin Endocrinol Metab 75:472-475, 1992

21. Gil-Cárdenas A, Herrera MF, Díaz-Polanco A, Rios JM, Pantoja JP: Nelson's syndrome after bilateral adrenalectomy for Cushing's disease. Surgery 141:147-152, 2007

22. Gross BA, Mindea SA, Pick AJ, Chandler JP, Batjer HH: Medical management of Cushing disease. Neurosurg Focus 23(3):E10, 2007

23. Gundgurthi A, Kharb S, Garg MK, Brar KS, Bharwaj R, Pathak HC, et al: Nelson's syndrome presenting as bilateral oculomotor palsy. Indian J Endocrinol Metab 17:11141116,2013

24. Guthrie FW Jr, Ciric I, Hayashida S, Kerr WD Jr, Murphy ED: Pituitary Cushing's syndrome and Nelson's syndrome: diagnostic criteria, surgical therapy, and results. Surg Neurol 16:316-323, 1981

25. Hawn MT, Cook D, Deveney C, Sheppard BC: Quality of life after laparoscopic bilateral adrenalectomy for Cushing's disease. Surgery 132:1064-1069, 2002

26. Heaney AP: Novel pituitary ligands: peroxisome proliferator activating receptor-gamma. Pituitary 6:153-159, 2003

27. Heaney AP, Fernando M, Melmed S: PPAR-gamma receptor ligands: novel therapy for pituitary adenomas. J Clin Invest 111:1381-1388, 2003

28. Heaney AP, Fernando M, Yong WH, Melmed S: Functional PPAR-gamma receptor is a novel therapeutic target for ACTH-secreting pituitary adenomas. Nat Med 8:1281-1287, 2002

29. Herman V, Fagin J, Gonsky R, Kovacs K, Melmed S: Clonal origin of pituitary adenomas. J Clin Endocrinol Metab 71:1427-1433, 1990

30. Hofland LJ, Lamberts SW: The pathophysiological consequences of somatostatin receptor internalization and resistance. Endocr Rev 24:28-47, 2003

31. Hornyak M, Weiss MH, Nelson DH, Couldwell WT: Nelson syndrome: historical perspectives and current concepts. Neurosurg Focus 23(3):E12, 2007

32. Imai T, Funahashi H, Tanaka Y, Tobinaga J, Wada M, Morita-Matsuyama T, et al: Adrenalectomy for treatment of Cushing syndrome: results in 122 patients and long-term follow-up studies. World J Surg 20:781-787, 1996

33. Jenkins PJ, Trainer PJ, Plowman PN, Shand WS, Grossman AB, Wass JA, et al: The long-term outcome after adrenalectomy and prophylactic pituitary radiotherapy in adrenocorti- 
cotropin-dependent Cushing's syndrome. J Clin Endocrinol Metab 80:165-171, 1995

34. Kasperlik-Załuska AA, Nielubowicz J, Wisławski J, Hartwig W, Załuska J, Jeske W, et al: Nelson's syndrome: incidence and prognosis. Clin Endocrinol (Oxf) 19:693-698, 1983

35. Kasperlik-Załuska AA, Zgliczyński W, Jeske W, Zdunowski P: ACTH responses to somatostatin, valproic acid and dexamethasone in Nelson's syndrome. Neuroendocrinol Lett 26:709-712, 2005

36. Katznelson L: Sustained improvements in plasma ACTH and clinical status in a patient with Nelson's syndrome treated with pasireotide LAR, a multireceptor somatostatin analog. J Clin Endocrinol Metab 98:1803-1807, 2013

37. Kelestimur F, Utas C, Ozbakir O, Selçuklu A, Kandemir O, Ozcan N: The effects of octreotide in a patient with Nelson's syndrome. Postgrad Med J 72:53-54, 1996

38. Kelly DF: Transsphenoidal surgery for Cushing's disease: a review of success rates, remission predictors, management of failed surgery, and Nelson's Syndrome. Neurosurg Focus 23(3):E5, 2007

39. Kelly PA, Samandouras G, Grossman AB, Afshar F, Besser GM, Jenkins PJ: Neurosurgical treatment of Nelson's syndrome. J Clin Endocrinol Metab 87:5465-5469, 2002

40. Kelly W, Adams JE, Laing I, Longson D, Davies D: Longterm treatment of Nelson's syndrome with sodium valproate. Clin Endocrinol (Oxf) 28:195-204, 1988

41. Kelly WF, MacFarlane IA, Longson D, Davies D, Sutcliffe H: Cushing's disease treated by total adrenalectomy: long-term observations of 43 patients. Q J Med 52:224-231, 1983

42. Kemink L, Pieters G, Hermus A, Smals A, Kloppenborg P: Patient's age is a simple predictive factor for the development of Nelson's syndrome after total adrenalectomy for Cushing's disease. J Clin Endocrinol Metab 79:887-889, 1994

43. Kemink SA, Grotenhuis JA, De Vries J, Pieters GF, Hermus AR, Smals AG: Management of Nelson's syndrome: observations in fifteen patients. Clin Endocrinol (Oxf) 54:45-52, 2001

44. Kovacs K, Horvath E, Syro LV, Uribe H, Penagos LC, Ortiz LD, et al: Temozolomide therapy in a man with an aggressive prolactin-secreting pituitary neoplasm: morphological findings. Hum Pathol 38:185-189, 2007

45. Lanzi R, Montorsi F, Losa M, Centemero A, Manzoni MF, Rigatti P, et al: Laparoscopic bilateral adrenalectomy for persistent Cushing's disease after transsphenoidal surgery. Surgery 123:144-150, 1998

46. Leber KA, Berglöff J, Pendl G: Dose-response tolerance of the visual pathways and cranial nerves of the cavernous sinus to stereotactic radiosurgery. J Neurosurg 88:43-50, 1998

47. Liu JK, Fleseriu M, Delashaw JB Jr, Ciric IS, Couldwell WT: Treatment options for Cushing disease after unsuccessful transsphenoidal surgery. Neurosurg Focus 23(3):E8, 2007

48. Loli P, Berselli ME, Vignati F, De Grandi C, Tagliaferri M: Size reduction of an ACTH-secreting pituitary macroadenoma in Nelson's syndrome by sodium valproate: effect of withdrawal and re-institution of treatment. Acta Endocrinol (Copenh) 119:435-442, 1988

49. Lüdecke DK, Breustedt HJ, Brämswig J, Köbberling J, Saeger W: Evaluation of surgically treated Nelson's syndrome. Acta Neurochir (Wien) 65:3-13, 1982

50. Marek J, Ježková J, Hána V, Kršek M, Liščák R, Vladyka V, et al: Gamma knife radiosurgery for Cushing's disease and Nelson's syndrome. Pituitary [epub ahead of print], 2014

51. McCance DR, Russell CF, Kennedy TL, Hadden DR, Kennedy L, Atkinson AB: Bilateral adrenalectomy: low mortality and morbidity in Cushing's disease. Clin Endocrinol (Oxf) 39:315-321, 1993

52. McNicol AM, Carbajo-Perez E: Aspects of anterior pituitary growth, with special reference to corticotrophs. Pituitary 1:257-268, 1999

53. Mercado-Asis LB, Yanovski JA, Tracer HL, Chik CL, Cutler
GB Jr: Acute effects of bromocriptine, cyproheptadine, and valproic acid on plasma adrenocorticotropin secretion in Nelson's syndrome. J Clin Endocrinol Metab 82:514-517, 1997

54. Moore TJ, Dluhy RG, Williams GH, Cain JP: Nelson's syndrome: frequency, prognosis, and effect of prior pituitary irradiation. Ann Intern Med 85:731-734, 1976

55. Moreira AC, Castro M, Machado HR: Longitudinal evaluation of adrenocorticotrophin and beta-lipotrophin plasma levels following bilateral adrenalectomy in patients with Cushing's disease. Clin Endocrinol (Oxf) 39:91-96, 1993

56. Moyes VJ, Alusi G, Sabin HI, Evanson J, Berney DM, Kovacs K, et al: Treatment of Nelson's syndrome with temozolomide. Eur J Endocrinol 160:115-119, 2009

57. Mullan KR, Leslie H, McCance DR, Sheridan B, Atkinson AB: The PPAR-gamma activator rosiglitazone fails to lower plasma ACTH levels in patients with Nelson's syndrome. Clin Endocrinol (Oxf) 64:519-522, 2006

58. Nagesser SK, van Seters AP, Kievit J, Hermans J, Krans HM, van de Velde CJ: Long-term results of total adrenalectomy for Cushing's disease. World J Surg 24:108-113, 2000

59. Nelson DH, Meakin JW, Dealy JB Jr, Matson DD, Emerson $\mathrm{K}$ Jr, Thorn GW: ACTH-producing tumor of the pituitary gland. N Engl J Med 259:161-164, 1958

60. Nelson DH, Meakin JW, Thorn GW: ACTH-producing pituitary tumors following adrenalectomy for Cushing's syndrome. Ann Intern Med 52:560-569, 1960

61. Nelson DH, Sprunt JG, Mims RB: Plasma ACTH determinations in 58 patients before or after adrenalectomy for Cushing's syndrome. J Clin Endocrinol Metab 26:722-728, 1966

62. Oldfield EH, Schulte HM, Chrousos GP, Gold PW, Benker G, Peterson RE, et al: Corticotropin-releasing hormone (CRH) stimulation in Nelson's syndrome: response of adrenocorticotropin secretion to pulse injection and continuous infusion of CRH. J Clin Endocrinol Metab 62:1020-1026, 1986

63. Ortiz LD, Syro LV, Scheithauer BW, Rotondo F, Uribe H, Fadul CE, et al: Temozolomide in aggressive pituitary adenomas and carcinomas. Clinics (Sao Paulo) 67 (Suppl 1):119123, 2012

64. Parsons JT, Bova FJ, Fitzgerald CR, Mendenhall WM, Million RR: Radiation optic neuropathy after megavoltage external-beam irradiation: analysis of time-dose factors. Int J Radiat Oncol Biol Phys 30:755-763, 1994

65. Patil CG, Prevedello DM, Lad SP, Vance ML, Thorner MO, Katznelson L, et al: Late recurrences of Cushing's disease after initial successful transsphenoidal surgery. J Clin Endocrinol Metab 93:358-362, 2008

66. Pereira MA, Halpern A, Salgado LR, Mendonça BB, Nery M, Liberman B, et al: A study of patients with Nelson's syndrome. Clin Endocrinol (Oxf) 49:533-539, 1998

67. Petrini L, Gasperi M, Pilosu R, Marcello A, Martino E: Long-term treatment of Nelson's syndrome by octreotide: a case report. J Endocrinol Invest 17:135-139, 1994

68. Pollock BE, Young WF Jr: Stereotactic radiosurgery for patients with ACTH-producing pituitary adenomas after prior adrenalectomy. Int J Radiat Oncol Biol Phys 54:839-841, 2002

69. Raffin-Sanson ML, de Keyzer Y, Bertagna X: Proopiomelanocortin, a polypeptide precursor with multiple functions: from physiology to pathological conditions. Eur J Endocrinol 149:79-90, 2003

70. Reincke M, Allolio B, Kaulen D, Jaursch-Hancke C, Winkelmann W: The effect of sodium valproate in Cushing's disease, Nelson's syndrome and Addison's disease. Klin Wochenschr 66:686-689, 1988

71. Resetić J, Reiner Z, Lüdecke D, Riznar-Resetić V, Sekso M: The effects of cortisol, 11-epicortisol, and lysine vasopressin on DNA and RNA synthesis in isolated human adrenocorticotropic hormone-secreting pituitary tumor cells. Steroids 55:98-100, 1990

72. Roelfsema F, Biermasz NR, Pereira AM: Clinical factors in- 
volved in the recurrence of pituitary adenomas after surgical remission: a structured review and meta-analysis. Pituitary 15:71-83, 2012

73. Schmid HA, Schoeffter P: Functional activity of the multiligand analog SOM230 at human recombinant somatostatin receptor subtypes supports its usefulness in neuroendocrine tumors. Neuroendocrinology 80 (Suppl 1):47-50, 2004

74. Shibasaki T, Masui H: Effects of various neuropeptides on the secretion of proopiomelanocortin-derived peptides by a cultured pituitary adenoma causing Nelson's syndrome. J Clin Endocrinol Metab 55:872-876, 1982

75. Shibasaki T, Nakahara M, Shizume K, Kiyosawa Y, Suda T, Demura H, et al: Pituitary adenomas that caused Cushing's disease or Nelson's syndrome are not responsive to ovine corticotropin-releasing factor in vitro. J Clin Endocrinol Metab 56:414-416, 1983

76. Shimon I, Ram Z, Cohen ZR, Hadani M: Transsphenoidal surgery for Cushing's disease: endocrinological follow-up monitoring of 82 patients. Neurosurgery 51:57-62, 2002

77. Sonino N, Zielezny M, Fava GA, Fallo F, Boscaro M: Risk factors and long-term outcome in pituitary-dependent Cushing's disease. J Clin Endocrinol Metab 81:2647-2652, 1996

78. Thomas CG Jr, Smith AT, Benson M, Griffith J: Nelson's syndrome after Cushing's disease in childhood: a continuing problem. Surgery 96:1067-1077, 1984

79. Tindall GT, Herring CJ, Clark RV, Adams DA, Watts NB: Cushing's disease: results of transsphenoidal microsurgery with emphasis on surgical failures. J Neurosurg 72:363-369, 1990

80. Tyrrell JB, Lorenzi M, Gerich JE, Forsham PH: Inhibition by somatostatin of ACTH secretion in Nelson's syndrome. J Clin Endocrinol Metab 40:1125-1127, 1975

81. van der Hoek J, Lamberts SW, Hofland LJ: The role of somatostatin analogs in Cushing's disease. Pituitary 7:257-264, 2004

82. van Wijk PA, van Neck JW, Rijnberk A, Croughs RJ, Mol JA: Proliferation of the murine corticotropic tumour cell line AtT20 is affected by hypophysiotrophic hormones, growth factors and glucocorticoids. Mol Cell Endocrinol 111:13-19, 1995
83. Vance ML: Cushing's disease: radiation therapy. Pituitary 12:11-14, 2009

84. Vik-Mo EO, Øksnes M, Pedersen PH, Wentzel-Larsen T, R $\varnothing$ dahl E, Thorsen F, et al: Gamma knife stereotactic radiosurgery of Nelson syndrome. Eur J Endocrinol 160:143-148, 2009

85. Weiss MH, Couldwell WT: Editorial. Gamma Knife surgery for Cushing disease. J Neurosurg 106:976-979, 2007

86. Whitehead HM, Beacom R, Sheridan B, Atkinson AB: The effect of cyproheptadine and/or bromocriptine on plasma ACTH levels in patients cured of Cushing's disease by bilateral adrenalectomy. Clin Endocrinol (Oxf) 32:193-201, 1990

87. Wilson PJ, Williams JR, Smee RI: Cushing's disease: a single centre's experience using the linear accelerator (LINAC) for stereotactic radiosurgery and fractionated stereotactic radiotherapy. J Clin Neurosci 21:100-106, 2014

88. Wolffenbuttel BH, Kitz K, Beuls EM: Beneficial gammaknife radiosurgery in a patient with Nelson's syndrome. Clin Neurol Neurosurg 100:60-63, 1998

89. Wynn PC, Harwood JP, Catt KJ, Aguilera G: Regulation of corticotropin-releasing factor (CRF) receptors in the rat pituitary gland: effects of adrenalectomy on CRF receptors and corticotroph responses. Endocrinology 116:1653-1659, 1985

\section{Author Contributions}

Conception and design: Liu. Acquisition of data: Patel. Analysis and interpretation of data: Patel. Drafting the article: Patel. Critically revising the article: all authors. Reviewed submitted version of manuscript: all authors. Approved the final version of the manuscript on behalf of all authors: Liu. Administrative/technical/ material support: Liu, Eloy. Study supervision: Liu, Eloy.

\section{Correspondence}

James K. Liu, Department of Neurological Surgery, Neurological Institute of New Jersey, Rutgers University, New Jersey Medical School, 90 Bergen St., Ste. 8100, Newark, NJ 07103. email: james.liu.md@rutgers.edu. 